\title{
Workmen's Compensation and Other Social Legislation: The Shadow of Stone Tablets
}

\author{
Stefan A. Riesenfeld*
}

We have come a long way from the time when courts were on guard to keep statutes in their place, in the shadow of the stone tablets of precedent. For a good many years now legislatures have been erecting some formidable stone tablets. of their own. ...†

When Governor Culbert Olson, a quartè of a century ago, called the then Professor Traynor from the lectern to the supreme court bench, he did so in days of gloom and strife. Hitler's war machinery was rolling across Europe and the issue of neutrahity for the United States was foremost in the mind of the general public. Moreover, the appointment came in the wake of an acrimonious controversy that had embroiled an eminent colleague of the nominee. Thus, if there was speculation abont the future accomplislıments of the new Justice, the daily papers reflected hittle thereof. Governor Olson was reported to have commented that he had selected "an able and competent lawyer." Today, wlien it is clear that the person lie so described has become one of the towering figures in the history of the American judiciary, the quotation seems to be one of the greatest understatements of our generation.

I

JUDICIAL CREATIVITY IN THE FIELD

OF LEGISLATION-ESPECIALLY SOCIAL IEGISIATION

The focus of this Article is the contribution of Chief Justice Traynor to the field of social legislation. A formidable problem looms at the threshold: Is the scope or texture of the normative creativity possible for a judge substantially different when he deals with statutes from what it is when lie operates in areas "still largely unclaimed by legislatures"? ${ }^{2}$ True, even in the field dominated by precedent, it would be what Cardozo has called "a false view of the landscape"3 if one were to think that there are no limits to a judge's law-making functions; yet the only true limits

* Dr. Jur., 1931, University of Breslau; Dott. in giur., 1934, University of Milan; LL.B., 1937, University of California; S.J.D., 1940, Harvard University; B.S., 1941, University of Minnesota; Professor of Law, University of California, Berkeley.

† Traynor, Comment on Courts and Lawmaking in Legal Institutions TODAY AND Tonarorow 48 (Paulsen ed. 1959).

${ }^{1}$ San Francisco News, July 31, 1940, p. 1, col. 1.

2 Traynor, Comment on Courts and Lawmaking, in Legal Instrutrons Today 48, 51 (Paulsen ed. 1959).

8 Cardozo, The Nature of the Judictat Process 129 (1922). 
are the avoidance of arbitrariness and unwarranted innovations. ${ }^{4} \mathrm{~A}$ judge ought not only to cultivate "waste spaces," staying away from acres already sown and fruitful," but he can, and indeed must, replace crops that have become unpalatable to modern tastes and wield forever the pruning knife sharpened by current needs and values. ${ }^{6}$ Legislation, on the other hand, casts a mold which a court is not free to disregard or recast in its entirety. Once the legislature has spoken (in a constitutionally vahid way) an area of shared responsibility is reached. The "trail of the calf" must now stay within certain confines. As Chief Justice Traynor has observed, "What a court does is determined in the main by the nature of the statute. It may be so general in scope as to invite judicial elaboration. It may evince such careful draftsmanship in the main as to render its errors egregious enough to be judicially recognized as such, inconsistent with the legislative purpose."

Statutes, then, to be meaningful need the same type of creative activity by the courts as do the basic common law subjects, although the outer bounds of judicial discretion, i.e., the ambit of policy choices, may be more confined in view of the legislative judgment." "A judge's range of techniques correctly available in deahing with statutes is roughly equivalent to the range correctly available in dealing with case materials." 10 Hence the standards of performance that can be expected of a great judge are as exacting in the field of statutory law as in more traditional areas. Certainly, Justice Traynor has not fallen short of his own mark.

The precise scope of social legislation-to borrow a phrase of $\mathrm{Mr}$. Justice Holmes ${ }^{11}$ - "is not a matter of principle or of very accurate history." Rather it is a term of convenience covering institutionalized programs designed to assure that each nember of society will be able to

4 About the "outer limits of judicial law-making," see Traynor, No Magic Words Could Do It Justice, 49 CAIIF. L. REv. 615, 620 (1961).

5 In a way, Cardozo, in using the simile quoted in the text, op. cit. supra note 3 , at 129 , seems to have overemphasized the "walls of the interstices."

6For an articulate impatience with "anachromistic precedents" see Traynor, note 4, supra, at 620-23; Traynor, op. cit. supra note 2, at 52-54. Even as a second year law student "R.J.T." championed the thesis that "neither abstract and theoretical notions on the one hand nor outgrown historical fictions on the other should stand in the way of necessary and beneficial results universally desired." Comment, 14 CaLIF. L. REv. 225, 229 (1925).

7 The calf-path simile with respect to the course of precedents was employed in Radin's brilliant essay, The Trail of the Calf, 32 CoRNExx L.Q. 137 (1946).

8 Traynor, op. cit. supra note 2 , at 63 , quoted by the author in note 4 supra at 619 .

O In addition to Chief Justice Traynor's writings, the opportunity and need for judicial "creative activity" in the various fields of statutory law is emphasized by Frank, CourTs ox TrLat 292, 308 (1949); in the same vein, Radin, called for a "Statesmanlike view" in A Short Way with Statutes, 56 HaRv. L. Rev. 388, 411 (1942).

10 Lieweliys, The Comaron Law Traditron Dectoming Appeats 371 (1960).

11 The Blackheath, 195 U.S. 361, 365 (1904). 
maintain a decent level of existence, either by means of income maintenance schemes or by provision of needed services or facilities otherwise outside the reach of low-income groups. ${ }^{12}$ Workmen's compensation, unemployment compensation, unemployment compensation disability benefits, categorical or general public assistance, and pubhic housing are probably the most important branches of this type of statutory law coming before state courts. The roots of American legislation manifesting the welfare function of the modern state reach far back into the early colonial days, ${ }^{13}$ but its full development is a child of the twentieth century, especially the eras of the two Roosevelts. When the present Chief Justice ascended to the bench of the Supreme Court of California, benefits under the federal Old Age and Survivors Insurance system had just become payable, two years earlier than originally planned. ${ }^{14}$

It is perhaps more than historic coincidence that Justice Traynor's first opimion, in the case of County of Alameda v. Janssen, ${ }^{15}$ was in the field of social legislation and gave him an opportunity to practice what lie had preached even as a student commentator. The controversy before the court involved the constitutionality of legislation which authorized the release of old age assistance liens ${ }^{16}$ and provided for the cancellation of agreements restraining the transfer or encumbrance of real estate executed theretofore by old age assistance recipients pursuant to a prior statutory mandate. ${ }^{17}$ It was contended that this legislation, to the extent that it authorized the release of liens, violated the state constitutional prohibitions agamst gifts of public money to individuals ${ }^{18}$ and special laws authorizing the impairment of liens, ${ }^{19}$ and that it amounted to an unlawful delegation of legislative authority. It was further claimed that the legislation, to the extent it required cancellation of the restrictive agreements, violated the constitutional guarantees against the impairment of contracts. A prior decision of the California Supreme Court in County of Los Angeles $v$. Jessu $p^{20}$ had indeed invalidated a prior legislative attempt ${ }^{21}$

12 For the history and the scope of the notion of "social legislation" see RresenfeID \& MaXweli, Modern Soctal Legislation 1-4 (1950). The credo of this type of legislation was aptly epitomized as early as 1900 in the Report of the Committee on Almshouses in the Annual Report of the State Board of Charities (New York) for the Year 1900: "The conditions of life and environment of no human being ought to be allowed to sink below a certain minimum standard." 1 id. at 513 .

13 See Riesenfeld, The Formative Era of American Public Assistance Law, 43 CaIIF.

L. REv, 175, 200 (1955).

14 Social Security Act Amendments of 1939, ch. 666, 53 Stat. 1360.

1516 Cal. 2d 276, 106 P.2d 11 (1940).

16 Cal. Stats, 1939, ch. 719, § 11, p. 2245.

17 Cal. Stats. 1940, ch. 11, §5, p. 29.

18 CaI. Consr. art. IV, § 31.

10 CaI. Const. art. IV, § 25.

2011 Cal. 2d 273, 78 P.2d 1131 (1938).

21 Cal. Stats. 1937, ch. 369, § 2225, p. 1094. 
to release old age assistance liens on the ground that it was unconstitutional as violative of the prohibitions against gifts to individuals and the impairment of contracts.

Justice Traynor, im upholding the new legislation, distinguished carefully the scope of the 1937 act from that of the 1939 act. He pointed out that, properly understood, the new statute provided for an expenditure for a legitimate public purpose rather than for a gift of public money to an individual. Since the operation of the new act was restricted to land that had not passed into the hands of third parties, the release of the lien served the same purpose of aiding the indigent aged himself as a direct grant of money. By the same token the cancellation of the restrictive agreements constituted a legitimate change of the contractual rights of political subdivisions rather than a proscribed impairment of contract. An intimation to the contrary contained in the County of Los Angeles case was disposed of with the characteristic candor and verve of the Traynor style: ${ }^{22}$ "The passing statement in County of Los Angeles v. Jessup, supra, that the legislation there in question was also constitutionally objectionable because of its impairment of the obligation of contract was unnecessary to the decision of the case, and upon fuller consideration appears to be without support in the authorities. It must, therefore, be deemed disapproved by our decision herein."

\section{III}

\section{WORKMEN'S COMPENSATION}

Workmen's compensation is the oldest social insurance system operating in the United States and, apart from some special federal programs, is left entirely to the judgment of state legislatures. The covered payrolls in California in 1964 exceeded the thirty billion dollar mark, and benefits paid under the program amounted to more than 225 million dollars. ${ }^{28}$ The economic repercussions of supreme court decisions in that field are therefore of considerable magmitude.

An optinal system of workmen's compensation presents perplexing problems to legislators and judges alike. Without rehearsing the famous Aristotelian differentiation between commutative and distributive justice suffice it to say that the aim of this type of legislation is not individualized redress but rather generalized relief. Compensation must be sure, adequate, and speedy at the price of completeness and refinement. Nevertheless, the mandates of due process must be carefully observed. Moreover,

2216 Cal. 2d 276, 284, 106 P.2d 11, 16 (1940).

23 The figures are furnished to the author by the California Division of Labor Statistics on the basis of data supplied by the self-insurers and the insurance carriers writing compensation insurance. 
California in particular leaves room for a variety of individual factors in the determination of the degree of permanent, partial disability. ${ }^{24}$ In practice the attributability of the injury to the employment, the earnings base of the disability indemnity benefits, and the determination of the effect of preexisting degenerative diseases upon work induced disabilities, apart from procedural matters, have presented thorny issues requirmg judicial resolution on the highest level. Chief Justice Traynor has left his mark on all these facets of the compensation law.

In Wiseman v. Industrial Accident Commission ${ }^{25}$ the court had to pass on the compensability of the death of an employee who had died of asphyxiation and burns in a hotel room in New York City while on a business trip. A woman, not his wife but registered as such, had shared the room with him and likewise perished. There was evidence to the effect that the fire had been caused by the careless smoking of one of the two accident victims and that both liad been drinking. The supreme court annulled an award by the Industrial Accident Commission denying death benefits and held that the death under the circumstances of the case arose out of and was proximately caused by the employment. Justice Traynor, writing for the inajority of the court, rejected the contention of cormsel for the respondent commission that the accident was noncompensable because the employee was occupying the room for an immoral and unlawful purpose and because the fire may have been due to the neghigence of the employee's companion rather than his own. The court held that the occupancy of the room was a necessary incident of the employment and that this relation was not destroyed by a concomitant private purpose of the employee. So long as the necessary employment connection was present the immorality or unlawfulness of the employee's conduct was irrelevant. Injuries caused by careless smoking while the employee is in the course of his employment are recognized risks of the employment, and it makes no difference whether the smoker is the employee himself or another. Simce it can be expected that a traveling employee will entertain guests who smoke in his room the connection between the injury and the employment was not so remote as to sever the incidental relationship. Obviously, a humanitarian interpretation of the law prevailed over a moralistic approach. An equally liberal view of the requisite employment connection of the injury was taken by Justice Traynor in California Casualty Exchange v. Industrial Accident Commission, ${ }^{26}$ involving the scope of the so-called coming and going rule. In that case an employee was

24 Cas. Labor Code $\$ 4660$, implemented by Schedule for Rating Permanent Disabilities adopted by the Industrial Accident Commission (by resolution of August 10, 1949 as amended).

2546 Cal. 2d 570, 297 P.2d 649 (1956).

2821 Cal. 2d 461, 132 P.2d 815 (1942). 
injured on her way home while riding in a company car driven by a fellow employee. The car was supplied by the employer as a convenience for the employees, the latter being at hiberty to use or not to use the facility, but subject to a wage deduction if they chose to do so. The employees performed certain services while en route. The accident was held to be covered. "The essential prerequisite to compensation," wrote Justice Traynor, "is that the danger from which the injury results be one to wlich he is exposed as an employee in his particular employment. This requirement is met when, as an employee and solely by reason of his relationship as such to his employer, he enters a vehicle regularly provided by his employer for the purpose of transporting him to or from the place of employment." While the injection of the word "solely" might be an unnecessary qualification the test again shows an enlightened policy with respect to coverage.

Perhaps the most important and controversial opmion of the Chief Justice in the field of workmen's compensation is his enunciation of the so-called "Montana rule" with respect to the determination of the controlling earning base. ${ }^{27}$ Disability benefits in workmen's compensation in California are structured in terms of weekly benefits of varying duration amounting, subject to certain fioors and ceilings, to 61.75 percent of the "average weekly wage" of the injured worker. ${ }^{28}$ The "average weekly wage" thus forms the basis of computing weekly benefits for both temporary and permanent disability. ${ }^{29}$ The determination of the average weekly wage, however, is a difficult task since the employment listory and prospects of the injured employee niay be affected by a variety of factors resulting from the labor market situation as well as occupational and personal characteristics of the employee. The statute itself incorporates a four-pronged test dealing with regular employment at a normal work week, ${ }^{30}$ multiple employment, ${ }^{31}$ habitual employment at an irregular rate, ${ }^{32}$ and irregular employment. ${ }^{33}$ Where a claimant falls into tlie last mentioned category, weekly earnings are based on the average weekly earning capacity at the time of the injury estimated with due consideration

27 Argonaut Ins. Co. v. Industrial Acc. Comm'n 57 Cal. 2d 589, 371 P.2d 281, 21 Cal. Rptr. 545 (1962) ; California Comp. \& Fire Co. v. Industrial Acc. Comm'n, 57 Cal. 2d 598, 371 P.2d 285, 21 Cal. Rptr. 549. (1962); Califorma Comp. \& Fire Co. v. Industrial Acc. Comm'n, 57 Cal. 2d 600, 371 P.2d 287, 21 Cal. Rptr. 551 (1962).

28 The applicable statutory provisions compute weekly benefits as $65 \%$ of $95 \%$ of the average weekly earnings. CAC. LABOR CODE $\S \S 4653$ \& 4659(a), in conjunction with $\S 4453$.

29 CAL. LABOR CODE $\S \S 4653 \& 4659$ (a).

30 CAL. LABOR CODE § 4453 (a).

31 CAT. LABOR CODE \& 4453(b).

32 CaL. Labor Code \& 4453 (c).

33 CaL. Labor Code \& 4453 (d). 
to the employee's actual earmings. In a trilogy of pioneering opinions Justice Traynor laid down the rule that correct application of California Labor Code Section 4453 entails the result that "earning capacity, for the purposes of a temporary award, however, may differ from earning capacity for the purposes of a permanent award." ${ }^{34}$ In reaching this revolutionary conclusion the court examined the aims and policy of the earnings base as the pivot of the Cahifornia benefit formula. Commenting on section 4553(d), Justice Traynor wrote:

The purpose of this provision is to equalize for compensation purposes the position of the full-time, regularly employed worker whose earning capacity is merely a multiple of his daily wage and that of the worker whose wage at the time of injury may be aberrant or otherwise a distorted basis for estimating true earming power. It would hardly be consistent with that purpose to foreclose a worker from a inaxinum temporary or permanent award simply because a brief recession had forced him to work sporadically or at a low wage. Nor in making a permanent disability award would it be consistent with the purpose of the statute to base a finding of maximum earning capacity solely on a high wage, ignoring irregular employment and low income over a long period of time .... In making an award for temporary disability, the commission will ordinarily be concerned with whether an applicant would have continued working at a given wage for the duration of the disability. In making a permanent award, long term earning history is a reliable guide in predicting earning capacity, although in a variety of fact situations earning history alone may be misleading. ${ }^{35}$

Accordingly, the determination of the carning base for purposes of a permanent award may require a complex weighing of many elements. Justice Traynor histed by way of example the victim's "ability to work, his age and health, his willingness and opportunities to work, his skill and education, the general condition of the labor market, and employment opportunities for persons sunilarly situated. . . ."36 Even the determination of the earning base for a temporary award requires prediction of the earnings for the period of the disability.

The triplet decisions constitute a reformative attempt by the bench to develop suitable tests for the determination of the appropriate earnimg bases for awards for temporary and permanent disability, respectively, that will achieve social justice by correlating the governimg average wage with the short range and long range pre-injury earning prospects of the disabled worker. It may have come as a shock to the justices that their opinions evoked unusual outcries of dissatisfaction and clamors for legislative relief from employers, insurance carriers, and unions alike. Criti-

3457 Cal. 2d 589, 594, 371 P.2d 281, 284, 21 Cal. Rptr. 545, 548 (1962).

3557 Cal. 2d 589, 594-95, 371 P.2d 281, 283-84, 21 Cal. Rptr. 545, 547-48 (1962).

$36 \mathrm{Id}$. at 595,371 P.2d at 284,21 Cal. Rptr. at 548. 
cisms were levelled against the new standards on two counts, possessing various degrees of persuasiveness. Although the carriers ennerged as victors in two of the decisions, ${ }^{37}$ obtaining chances for a reduction of the awards in question, employers and carriers argued that the social justice meted out was not even-handed since the holding was apt to burden the employer or his insurance carrier with benefits not predicated on the employment and payment practices of the employer in whose employ the mjury occurred. Carriers im particular urged that the premium income out of which awards must be paid are based on the annual payrolls of the responsible employer. It is, however, clear that the statute inakes the disability of the enployee the principal measure of the size of the award. It recognizes therefore that the danger of an earning capacity of an employee greater than that reflected by the annual remuneration customary in an industry engaging in interunittent employment practices is an occupational hazard of that industry, which ultimately will manifest itself in higher premium rates for that risk class. The second ground of attack against the "Montana principle," however, is of greater cogency. Workmen's conipensation in California is supposed to be a self-administered system with the carriers or self-insurers making prompt payments of the proper announts without need for quasi-judicial determination. It is claimed that the built-in flexibility of the new tests have spawned an inordinate amount of controversies in the construction industry and other enterprises with intermittent job opportunities and thus greatly increased the already excessive litigiousness of the California system. Since California possesses no legislative schedule for enumerated physical impairnents but requires assessment of a variety of factors for determining permanent partial disability, the administration of workmen's compensation has changed increasingly into a "hearing systenn."38 The injection of a "Montana issue" into niany of these cases has greatly accentuated the deplorable situation. It seems, lowever, unavoidable that hitigation is the price of individualized justice. Perhaps it therefore transcends the compass of judicial legislation to work out a system which accomodates both the practical needs of a self-administered system of prompt and proper payment and the basic goal of appropriate relief for the work-injury victim. ${ }^{39}$ Certainly, the opinions deserve praise for not having lost sight of the fundamental premises.

37 Argonaut Ins. Co. v. Industrial Acc. Comm'n, 57 Cal. 2d 589, 371 P.2d 281, 21 Cal. Rptr. 549 (1962); California Comp. \& Fire Co. v. Industrial Acc. Comm'n, 57 Cal, 2d 600, 371 P.2d 287, 21 Cal. Rptr. 551 (1962).

38 About the various systems of compensation administration operating in the United States see Riesenfeid \& Maxwele, Modern Social Legistation 348 (1950).

39 To obviate the difficulties created in the construction industry by the Montana rule the California Labor Federation and California compensation insurance industry, in 
The opinion ${ }^{40}$ which first laid down the "Montana rule" is also significant because it contaims an important restatement of the principles governing apportionment. The record in that case contained evidence to the effect that the injured worker suffered from some degenerative changes in his back which, however, were not unusual in a man of his build and age. Justice Traynor held that the issue of whether a disability results, in a whole or in part, from the normal progress of a preexisting disease or represents a fully compensable highting up or aggravation of a dormant preexisting condition is primarily a factual question, depending principally on the commission's appraisal of the medical evidence produced. ${ }^{41}$

Justice Traynor is also the author of a series of important opinions concerning the proper procedure in contested claims. Allied Compensation Insurance Co. v. Industrial Accident Commission ${ }^{42}$ dealt with the requirements of a fair hearing in cases where the commission rejects the findings and award of the referee and proceeds upon the record in the case pursuant to Labor Code Section 5315. In the particular proceedings no transcript of the testimony of the accident victim given in the hearing by the referee was before the commission, and the panel acted solely upon the referee's summary of that testimony. The supreme court ruled that this procedure did not abridge the petitioner's right to a fair hearing since the commissioners had performed their obligation to achieve a substantial understanding of the record by any reasonable means, including the use of the referee's summary. Justice Traynor, writing for the court, rejected the commission's contention that a transcript of the testimony was not part of the record within the meaning of the Labor Code, but it equally disagreed with petitioner's argument that the commission was under an absolute duty to order and read a transcript. The court also clarified the scope of the right to a further hearing given by Labor Code Section 5704. Sinilar issues arose in Industrial Indemnity Co. v. Industrial Accident Commission. ${ }^{43}$ The court again held that failure to order and ex-

1964, concluded an agreement establishing an initial temporary disability rate of compensation to be paid to employees attached to the building trades industry. The stipulation provided full benefits based on wages at the time of the injury where the employer reports the employee as having a record of reasonably continuous employment or that it was contemplated that the employee was employed for an indefinite duration. In other cases the carrier was to pay initially full benefits based on wages at the time of the injury with the right to adjustment of future payments if the initial rate was found to be incorrect. Letter from Califorma Workmen's Compensation Institute, J. P. Taheny, President, to Howard Dickey and others, August 7, 1964. Copy on file in the office of the California Law Review.

40 Argonaut Ins. Co. v. Industrial Acc. Comm'n, 57 Cal. 2d 589, 371 P.2d 281, 21 Cal. Rptr. 545 (1962).

41 Id. at 593, 371 P.2d at 283, 21 Cal. Rptr. 546 (1962).

4257 Cal. 2d 115, 367 P.2d 409, 17 Cal. Rptr. 817 (1961).

4357 Cal. 2d 123, 367 P.2d 413, 17 Cal. Rptr. 821 (1961). 
amine the transcript of the testimony of the injured worker and reliance on the referee's summary was not as such a reversible error. The award, however, was reversed for the reason that the commission had accepted an occupational classification of the applicant different from that determined by the referee without giving the carrier an opportunity to introduce evidence as to the proper classification. The third case in this sequence is Fireboard Paper Products Corp. v. Industrial Accident Commission. ${ }^{44}$ There the panel had returned the case to the referee for the purpose of holding a hearing in which the rating specialist could be crossexamined. The referee admitted a medical report submitted by petitioner on the extent of the applicant's disability and permitted the applicant to testify in rebuttal. In its final decision the commission refused to consider this additional evidence. The court held that under Commission Rule 10774 the referee had the power to admit the report and the rebuttal testimony, that both thereby became a proper part of the record, and that the commission could not achieve a substantial understanding of the record when it refused to consider the additional evidence. The decisions slow the solicitude of Justice Traynor for a fair hearing without insistence on unnecessary procedural rigidity.

The last decision to be included in this appreciation of Chief Justice Traynor's contribution to the law of workmen's compensation is the much discussed opinion in Witt v. Jackson. ${ }^{45}$

In Witt v. Jackson, Justice Traynor was faced with the question whether an employer whose concurrent negligence contributed to an injury sustained by an employee owing also to the negligence of a third party tortfeasor may obtain reimbursement from the latter for the amount of compensation paid. The issue arose out of a motor vehicle accident in whicli two einployees of the City of Los Angeles were injured in the course of their employment. One of the two employees who was the driver of the car was guilty of contributory negligence for which the city was vicariously hable. The city contended that it could seek reimbursement from the negligent third party for the amount of compensation paid to the innocent employee. Justice Traynor quoted with approval the language contained in a North Carolina decision: "When the employee or his estate has been satisfied, and the employer seeks to recover the amount paid by him, from such third party, his liands ouglit not to have the blood of the dead or injured workman upon thein, when he thus invokes the impartial powers and processes of the law."46 Justice Traynor felt that this statement was a colorful paraplurase of the policy contained in Section 3517 of the

4457 Cal. 2d 844, 372 P.2d 321, 22 Cal. Rptr. 489 (1962).

4557 Cal. 2d 57, 366 P.2d 641, 17 Cal. Rptr. 369 (1961).

46 Id. at 71, 366 P.2d 649, 17 Cal. Rptr. at 377. 
California Civil Code which provides that "no one can take advantage of his own wrong." Since Labor Code Section 3852, in regulating the subrogation rights of the employer vis-à-vis a third party tortfeasor, contains no express declaration to the effect that the remedies there provided are available to a negligent employer, the court ruled that the general policy of the Civil Code prevailed and that contributory negligence of the employer barred his right of reimbursement. The decision produces the overall result that in a case of compensable injury inflicted upon an employee by the concurrent negligence of a third party and the employer, the former will be liable for the excess damages over and above the compensation benefits, while the latter or his compensation insurance carrier will bear the entire compensation burden. Althougl it has been suggested that the allocation scheme adopted by Witt is "the most equitable distribution," monetary burden on the third party tortfeasor will normally be heavier than that on the employer or the carrier, even where the extent of the employer's or carrier's burden is the incurred liability rather than the payments made at the time of the hitigation. ${ }^{48}$ It is, however, doubtful whether under the present realities of workmen's compensation the incurred hability-which covers all necessary medical expenses, benefits for temporary disability, and, where apposite, an indemnity for permanent disability-the share of the employer or his carrier will not nornally be substantially greater than the balance of the tort liability. A system which leads to an equitable division of the whole loss, according to the degree of culpability of the parties ${ }^{49}$ might ultimately be a fairer solution. However, such an apportionment would produce considerable practical difficulties in its administration. Moreover, eiglity-five percent of the dollar amount of the annual payrolls for workers in employment covered by workmen's compensation is insured with compensation carriers who receive premiums for their exposure. ${ }^{50}$ Finally, and most important of all, a rule which leaves the compensation liability in toto on the negligent employer or his carrier and precludes any decrease or increase because of the size of the total loss sustained by the employee seems to be consonant with the legislative policy of the 1959 amendment of Califorma Labor Code Section 3864 which shields an employer against an action by a third party for reimbursement or imdemnification in the absence of a written agreement. ${ }^{51}$ Justice Traynor's decision, therefore, mamfests wise

47 Note, 50 CaIIF. L. Rev. 571, 575 (1962).

48 For a discussion of this point, see id. at 578-579.

49 The disregard of the degree of culpability in the Witt rule is discussed id. at 574 .

50 About the social significance of this element, see id. at $576 \mathrm{n} .31$.

51 See the reference to the parallel policy of Labor Code $\S 3864$ in Witt v. Jackson, 57 Cal. 2d 57, 73366 P.2d 641, 650, 17 Cal. Rptr. 369, 378 (1961); City of Sacramento v. 
judicial statesmanship in simply forestalling a situation which would permit an employer, who but for the compensation system would be responsible in tort, to umload his compensation liability on a joint tortfeasor, and im leaving more extensive refinements or adjustments to fuller legislative action.

\section{III}

\section{UNEMPIOYMENT COMPENSATION}

Unemployment compensation is the other social security system which vies with workmen's compensation for settlement of controversial issues by state courts. While in recent years the aggregate of annual benefits paid under unemployment insurance has greatly exceeded that paid under workmen's compensation, the comparatively smaller size of the individual benefit amounts has rendered unemployment compensation somewhat less litigious than workmen's compensation. Nevertheless, the supreme court has been called upon in a number of cases to determine important issues regarding substantive and procedural aspects of the governing legislation. ${ }^{52}$ In 1944 Justice Traynor authored a package of opinions ${ }^{53}$ which clarified a broad array of difficult and controversial issues that had arisen in the early days of the administration of the act, and subsequently he lias written additional opinions developing the applicable law. ${ }^{64}$ Coverage, eligibility and disqualification, standing to contest claims, scope of rulemaking powers, and similar issues were the grist of the judicial mill.

Of this group of 1944 cases, the Matson Terminals case, the American-Hawaiian Steamship Co: case, and the W. R. Grace $\&$ Co. case all grew out of certain waterfront labor troubles during 1939. The first two litigations arose out of a strike called by the Ship Clerks' Union against the members of a waterfront einployers' association; the Matson Terminals case involved longshoremen as claimants, while the AmericanHawaiian Steamship case concerned the claims of certain classes of

Superior Court, 205 Cal. App. 2d 398, 403-05, 23 Cal. Rptr. 47, 48 (1962); American Can Co. v. City \& County of San Francisco, 202 Cal. App. 2d 520, 524, 21 Cal. Rptr. 33, 35 (1962).

52 Unemployment Insurance Act, 1935, 1935 Stat. ch. 352, p. 1226, replaced in 1953 by the Cax. UNEMTPL. Ins. Code, 1953, Stat. ch. 308, p. 1457.

53 Matson Terminals, Inc. v. California Employment Comm'n, 24 Cal. 2d 695, 151 P.2d 202 (1944); American-Hawaiian S. S. Co. v. California Employment Comm'n, 24 Cal. 2d 716, 151 P.2d 213 (1944); W. R. Grace \& Co. v. California Employment Comm'n, 24 Cal. 2d 720, 151 P.2d 215 (1944); Bunny's Waffle Shop, Inc. v. California Employment Comm'n, 24 Cal. 2d 735, 151 P.2d 224 (1944); Mark Hopkins Inc. v. Califorma Employment Comm'n, 24 Cal. 2d 744, 151 P.2d 229 (1944); Whitcomb Hotel, Inc. v. California Employment Comm'n, 24 Cal. 2d 753, 151 P.2d 233 (1944).

54 E.g., Isenberg v. California Employment Stabilization Comm'n 30 Cal. 2d 34, 180 P.2d 11 (1947); Thomas v. California Employment Stabilization Comm'n, 39 Cal. 2d 501, 247 P.2d 561, 564 (1952) (concurring opimion). 
checkers. The W.R. Grace \& Co. case, conversely, involved an earlier labor dispute between the Ship Clerks' Union and the maritime employers, with longshoremen being the claimants; the factual difference between the Matson case and the Grace case was that in the former case the Ship Clerks' Union had called a strike against all members of the Waterfront Employers' Association, while in the Grace case a strike liad been called only against one member of that association, and the other nembers had responded with a lockout.

All three decisions determined the standing of employers to compel, by writ of mandate, the then California Employment Commission to vacate an order awarding unemployment benefits, with the effect that no further benefits are payable; all three also involved a construction of the trade dispute disqualification. Since the holding on the first issue prompted quick amendment of the act and subsequent statutory changes ${ }^{55}$ no further comments are in order. The continuing value of the opinions remams in their interpretation of the trade or labor dispute qualification in the statute. ${ }^{58}$ The commission had taken the view that neither the longshoremen nor the checkers involved in the Matson case and the American-Hawaiian Steamship case were affected by the labor dispute section since under the hirmg practices for longshoremen and checkers pursued by the maritime employers in San Francisco it could neither be said that the claimants had left work in which they had been employed nor that there was a strike in progress in the establishment in which they had been employed. Justice Traynor rejected a construction resting on such technicalities. He held that since the claimants had refused to avail themselves of jobs to which they were entitled in order to remain faithful to their union principles, the labor dispute disqualification came into operation. ${ }^{57}$

In the Grace $^{58}$ case, the lockout of the checkers by the employers against whom no strike had been called by the Ship Clerks' Union was

551945 Stats. ch. 1369 , p. 2558 ; 1947 Stats. ch. 1436, \& 3, amending $\& 68 \mathrm{~b}$, now CaL. UNEMTPL. INS. CODE \& 1335.

56 CAT. UNEMrI. INS. CODE \& 1262, rendering an employee who "left his work because of a trade dispute ... . for the period which he continues out of work by reason of the fact that the trade dispute is still in active progress in the establishment in which he was employed." The original act, §56(a) was substantially the same.

67 An overly broad interpretation by the Unemployment Appeals Board of the test laid down by Justice Traynor subsequently involved the State in a conformity proceeding under $\$ 1603(a)(5)$ of the Internal Revenue Code of 1939. In view of an indicated correction of the principles to be followed henceforth, no formal decision by the Secretary of Labor was rendered. Secretary of Labor, 38 ANNUAI REPORT 135 (1950). The validity of Justice Traynor's analysis has remained ummpaired, Ruberoid Co. v. California Unempl. Ins. App. Bd. 59 C.2d 73, 378 P.2d 102, 27 Cal. Rptr. 878 (1963).

58 W. R. Grace \& Co. v. California Employment Comm'n, 24 Cal. 2d 720, 151 P.2d 215 (1944). 
followed by differing treatment of the longshoremen. Some were told not to begin work unless they were willing to continue to work without checkers, others left their work when they reached the stage where checkers are usually employed, and still others were told to return to the hiring hall regardless of whether they were willing to work without checkers. The court held that longshoremen who were told to return to the hiring hall without having refused to work without checkers had not left because of a labor dispute and were entitled to benefits. The other groups, however, had rendered themselves inehgible under the labor dispute qualification. Justice Traynor rejected an argument that the conduct of the unsuccessful claimants fell under the limited discualification provided for those who voluntarily leave work without good cause. ${ }^{50}$ He held that the labor dispute disqualification governed the status of the claimants who refused to work or continue to work without the locked out checkers.

The dividing line between leaving because of a trade dispute and leaving for other causes, good or bad, was also the central issue in Bunny's Waffle Shop v. California Employment Comm'n. ${ }^{60}$ In that case the employers in the course of a dispute with the union demanding higher wages, as a matter of economic coercion, lowered the wages below the former level with the result that the claimants quit. Justice Traynor held that reaction against the employers' strategy prompted the leaving rather than a will to participate in the dispute and that under the circumstances of the case good cause for their leaving existed.

Mark Hopkins, Inc. v. California Employment Comm'n $n^{01}$ made necessary the determination of what type of employment obtained by a worker leaving because of a labor dispute was needed to terminate the labor dispute disqualification. Justice Traynor ruled that subsequent employment to terminate that disqualification must be such that it breaks the continuity of the claimant's unemployment and the causal connection between his unemployment and the trade dispute. Such employment must be bona fide and not merely a sham. Mere temporary, casual, or part time work does not meet the test. In the case at bar the evidence required a finding that no bona fide permanent employment in a new job was souglit or obtained.

In Whitcomb Hotel v. California Employment Comm'n ${ }^{62}$ Justice Traynor finally dealt with the duration of the disqualification resulting from a failure, without good cause, to accept suitable employment. The statute at that time failed to specify that the disqualification was only for

59 CaL. Unempl. Ins. Code $\S 1256$, formerly Unemployment Insurance Act $\S 58(a)$.

6024 Cal. 2d 735, 151 P.2d 224 (1944).

6124 Cal. 2d 744, 151 P.2d 229 (1944).

6224 Cal. 2d 753, 151 P.2d 233 (1944). 
a limited period, and the court concluded that only subsequent employment could cure the ineligibility. A rule of the commission which had supplied a durational limitation was held to be unauthorized, thereby necessitating an amendment of the act. ${ }^{63}$ The court felt that it must resist the temptation to overlook the lack of power in the commission.

In Isenberg v. California Employment Stabilization Comm'n $n^{64}$ the court was confronted with the issue of whether free lance jockeys were in "employment" within the meaning of the act. It reversed a judgment of the court below which had ruled in the negative. Justice Traynor, speaking for the majority, held that the race track owner possessed sufficient economic control over the jockeys to render thein employees. Since the court liad already uplreld a determination that the jockeys were covered by the workmen's compensation act, consistency between the two systems of legislation required the same conclusion for the unemployment insurance act.

\section{CONCLUSION}

The foregoing survey, of course, can only summarize the issues before the court and their resolution. It cannot convey to the reader an impression of the superb craftsmanship of the opmions, of their breadth, and their depth. The liallmark of the Traynor style is the care and skill with which existing authorities are collected and marshalled as well as the thoughtfulness and intelligence with which the underlying policy considerations are analyzed and balanced. As a result, the opimons disclose clearly the factors which were deemed relevant $m$ the line of development represented by the particular decision. The opmions cliosen for discussion of Justice Traynor's contribution to the law governing unemployment compensation show his efforts to forge the loosely connected and blurred sections of a compreliensive statutory scheme into a coherent and solid whole with sharply defined contours for each component. The opinions dealing with workmen's compensation reveal his capacity for giving new directions and meaning to parts of a statute whicl theretofore had been taken too inuch at face value. Of course, in some instances, the confinement of the statutory mandates stifled even Justice Traynor's creativity.

Nearly all Traynor opinions are virtual casebook material because of their thoroughness and analytical excellence. What is so remarkable, however, is not that feature alone, but that so many of thein are indelible milestones of law reform. It is that latter feature whicl makes the judicial harvest of Justice Traynor's twenty-five years on the bench the object of deserved acclaim from the profession. 
Although his great modesty would never permit the Chief Justice to utter the proud self-appraisal which is ascribed to one of the great Germamic law reformers half of a millennium ago, ${ }^{65}$ he certainly would be entitled to repeat the celebrated lines fron the Proenvium to the Sachsenspiegel:

Mancher wenet ein meister sin

binnen sinem krenge,

der kume were en meisterlin, life lier mit mir de lenge. ${ }^{66}$

65 Eike von Repkow, born c. 1180, author of the famous MTRROR of THE SAxoNs.

68

Many a one may be deemed a master

within his own bailiwick,

but he would hardly be even a hittle master

were he in a race with me.

SACrSENSPIEGEX 12 (Schwerin ed. 1956) (Riesenfeld transl.) 